\title{
PENGARUH LOAN TO DEPOSITE RATIO, RETURN ON ASSETS, CAPITAL ADEQUACY RATIO, EXCHANGE RATE DAN INTEREST RATE TERHADAP RETURN SAHAM
}

\author{
Ketut Asmara Jaya \\ Sekolah Tinggi Ilmu Ekonomi Sailendra Jakarta \\ Email: stie_sailendra@yahoo.co.id
}

\begin{abstract}
Growth of Capital market in late 2010 showed outstanding performance with rising of stock return which is influenced by various factors, both internal factors and external factors of each company it self. This study analyzes the Loan To Deposite Ratio (LDR), Return On Assets (ROA), Capital Adequacy Ratio (CAR), Exchange Rate and Interest Rate impact on stock returns in corporate banking. This study uses panel data with LM Test statistical calculation it is shown that Random Effect method is more precise to be used in this study. The result of the study shown that ROA variable gives positive and significant influence in stock return. While LDR, variables CAR and exchange rate of no influence and significantly to return stock, and only tendency if LDR, CAR and exchange rate increase then return shares can be increased as well. The Interest Rate variable did not give positive and significant influence because of not having relationship with stock return.
\end{abstract}

Keywards: Ldr, Roa, Car, Exchange Rate, Interest Rate, Return Saham

\begin{abstract}
Abstrak: Pertumbuhan pasar modal pada akhir tahun 2010 menunjukkan kinerja yang luar biasa dengan meningkatnya kembali nilai saham dengan dipengaruhi oleh berbagai faktor, baik faktor internal ataupun faktor eksternal dari setiap perusahaan. Studi ini menganalisis untuk pinjaman deposit rasio (LDR), pengembalian asset (ROA), rasio kecukupan modal (CAR), nilai tukar dan suku bunga yang berdampak pada keuntungan saham di perusahaan perbankan. Studi panel ini menggunakan data $L M$ test statistik yang menunjukkan perhitungan metode random effect adalah cara yang lebih tepat digunakan untuk mengestimasi model dalam penelitian ini. Hasil studi menunjukkan bahwa variabel ROA memberikan pengaruh positif dan signifikan dalam return saham. Sedangkan variabel $L D R, C A R$ dan Kurs tidak ada pengaruh yang signifikan terhadap return saham, dan hanya kecenderungan jika $L D R$, $C A R$ dan Kurs meningkat maka return saham dapat meningkat pula Suku bunga variabel tidak memberikan pengaruh positif dan pengaruh signifikan karena tidak memiliki hubungan dengan return saham.
\end{abstract}

Kata kunci: LDR, ROA, CAR, EXCHANGE RATE, Interest Rate, Return Saham

\section{PENDAHULUAN}

Kemajuan pasar modal di pasar modal Indonesia salah satunya adalah emiten yang berasal dari industri perbankan yang turut menyumbang kenaikan IHSG di BEI. Adapun pengertian dari pasar modal merupakan pasar dengan berbagai instrumen keuangan jangka panjang yang biasa diperjualbelikan, baik dalam bentuk utang, saham, instrument derivatif, maupun instrumen lainnya (Tjiptono \& Hendy, 2008). Salah satu kelebihan dari 
pasar modal adalah kemampuannya menyediakan modal dalam jangka panjang dan tanpa batas (Sawidji, 2009).

Perusahaan yang go publik disebut emiten dan pemilik modal disebut investor, pemodal akan mendapatkan return berupa selisih dari jual beli saham, kemungkinan mendapatkan dividen bila emiten mendapatkan laba. Dilihat dari pertumbuhan pasar modal itu sendiri tercermin dengan penguatan IHSG sebesar 46,13\% akhir tahun 2010 dibandingkan dengan tahun 2009. Indonesia merupakan salah satu negara G-20 dengan investment return yang paling tinggi, mengingat perbedaan tingkat suku bunga yang besar sehingga potensi laba sektor perbankan mengalami peningkatan, berakibat kenaikan return saham perbankan (Nurul, 2010). Kinerja dari sektor perbankan mengalami kenaikan salah satunya dari pendapatan atas kredit macet yang dapat ditagih ataupun upaya-upaya lain sehingga meningkatkan laba perbankan. Pada sektor perbankan mengalami pertumbuhan pada tahun 2010 dibandingkan dengan tahun 2009 sebesar 55,15\%, yang mempunyai andil yang cukup besar dalam kegiatan aktivitas di pasar modal dan besarnya animo investor terhadap sektor perbankan. Pencapaian IHSG keseluruhan dan IHSG sektor perbankan pada tahun 2010 masing-masing sebesar 3.704 dan 467 merupakan pencapaian tertinggi selama kurun waktu periode penelitian. Besarnya peningkatan IHSG perbankan dengan 55,15\% tersebut membuktikan bahwa saham-saham perbankan salah satu penopang sekaligus penggerak IHSG.

Alasan pemilihan saham-saham pada sektor perbankan dengan melihat pertumbuhan IHSG dan return yang tinggi pada tahun 2010, bahwa pada sektor perbankan dengan kapitalisasi pasar sebesar 23,40\% yang berarti berpengaruh terhadap IHSG. Return saham yang tinggi tidak terlepas dari kinerja perusahaan itu sendiri (seperti pertumbuhan laba, peningkatan aktiva) dan dari luar perusahaan seperti pengaruh suku bunga, kurs, inflasi dan lainnya. Dalam melakukan analisa tentunya diperlukan data-data baik dengan menggunakan analisa fundamental yang mencoba memperkirakan harga saham dengan faktor-faktor fundamental perusahaan seperti kebijakan penjualan, pertumbuhan penjualan, kebijaksaaan pemerintah, perkembangan tingkat bunga dan lainnya yang dapat mempengaruhi harga. Analisa teknikal yang tidak memperhatikan faktor-faktor fundamental dengan mengamati perubahan harga saham (kondisi pasar) di waktu yang lalu (Husnan, 2005). Dalam penelitian ini ingin membuktikan pengaruh faktor internal dan pengaruh faktor eksternal terhadap return saham. Faktor internal yang meliputi informasi akuntansi lainnya, sebagai kriteria pemilihan saham sektor perbankan dilihat dari kinerja yang menunjukkan tren yang membaik seperti meningkatnya Loan to Deposit Ratio (LDR).

Pada penelitian ini ada beberapa rasio sebagai faktor internal, yaitu komponen yang penting pada rasio permodalan adalah Capital Adequacy Ratio (CAR) . Pada rasio likuiditas adalah Loan Deposit Ratio (LDR) yang merupakan ratio antara kredit yang diberikan kepada pihak ketiga terhadap dana pihak ketiga yaitu giro, tabungan dan deposito (tidak termasuk dana antar bank) (SE BI No.3/30/DPNP tanggal 14 Desember 2001), efisiensi didalam penggunaan modal yang tepat dapat menghasilkan tingkat laba yang diharapkan, dan terhadap pengelolaan aset yang tepat perusahaan dapat melakukan efisiensi terhadap pemilihan aset yang tersedia sehingga dengan mengetahui rasio profitabilitas dengan komponen Return On Assets (ROA) dapat diharapkan keuntungan meningkat. Asna dan Graha (2006) yang menganalisa kinerja keuangan perusahaan sektor perbankan dengan melihat kinerja finansialnya dengan return saham mendapatkan hasil bahwa $L D R$ dan $B O P O$ yang berpengaruh terhadap return saham. Timbul dan Nugroho (2009) yang menganalisa $E V A, R O A, R O E$ dan persentase kepemilikan modal saham asing terhadap harga saham berpendapat EVA, ROA dan persentase kepemilikan modal saham 
asing yang berpengaruh terhadap harga saham. Hartono dan Sihotang (2009), menyimpulkan bahwa terhadap rasio $R O E$, NPM dan $R O A$ hasilnya hanya $R O E$ saja yang memperikan pengaruh yang cukup signifikan terhadap pergerakan harga saham sedangkan NPM dan ROA tidak memberikan pengaruh terhadap pergerakan harga saham. Faktor Eksternal yang meliputi pengaruh suku bunga, kurs, dan lainnya, merupakan faktor diluar kontrol perusahaan, sehingga perbankan dalam hal ini akan selalu mengamati setiap perubahan beserta antisipasinya.

Adanya konstraksi moneter dengan menaikkan suku bunga, menurunkan pengeluaran akan berakibat menurunkan pendapatan (Dorbusch, Fischer dan Startz, 2008), mengakibatkan perekonomian tidak stabil, investor menjual sahamnya untuk diinvestasikan ke produk yang berbasis suku bunga sehingga mempengaruhi pemilihan investasi. Henry (1993) menyatakan bahwa suku bunga tidak ditemukan hubungan yang signifikan terhadap harga saham sedangkan Sembiring (2009), berpendapat reksadana campuran yang portofolionya didominasi oleh saham dan deposito dipengaruhi dari besarnya pengaruh IHSG dan suku bunga SBI yang menjadi indikator pergerakan terhadap nilai aktiva bersih reksadana. Sridadi (2005), meneliti Indeks Harga Saham Gabungan (IHSG), right issue, kurs dollar, dan tingkat suku bunga Singapore Internasional Bank Offered Rate (SIBOR) terhadap volume perdagangan dengan hasil penelitiannya IHSG, right Issue, maupun nilai tukar rupiah terhadap dolar berpengaruh signifikan terhadap volume perdagangan sedangkan suku bunga tidak mempunyai pengaruh terhadap volume perdagangan. Peranan kurs terhadap perekonomian suatu negara mempunyai pengaruh yang langsung ataupun secara langsung dirasakan. Kenaikan kurs yang terjadi pada perekonomian saat krisis di tahun 1997 membuktikan terjadinya hiper inflasi dengan melakukan kebijakan kenaikan suku bunga yang tinggi berakibat perekonomian stagnan. Dengan melakukan pengawasan oleh otoritas moneter yaitu Bank Indonesia diharapkan kenaikan kurs yang tinggi dapat dihindarkan, sehingga lonjakan pembelian USD tidak terjadi, masuknya investasi dari luar negeri. Bustami (2002), dengan penelitiannya menyatakan bahwa dampak dari tingginya perubahan nilai tukar (kurs) mempunyai pengaruh besar terhadap return saham, sehingga pengelola bursa diharapkan harus mampu meningkatkan kinerja untuk mendapatkan effesiensi di dalam pasar modal. Peneliti oleh Ulupui (2007), dengan menggunakan metode vector auto regression (VAR) menggambarkan pengaruh kurs mempengaruhi nilai terhadap IHSG. Berkaitan dengan hal-hal tersebut, maka studi ini menganalisa pengaruh loan deposit ratio (LDR), return on asset (ROA), capital adequacy ratio (CAR), kurs dan suku bunga terhadap return saham dengan mengambil kasus pada sektor perbankan yang tercatat pada Bursa Efek Indonesia pada periode bulanan dari tahun 2005 sampai dengan tahun 2010. Berdasarkan latar belakang masalah dengan adanya faktor internal yang diduga berpengaruh yaitu pada rasio likuiditas dengan loan to deposit ratio, rasio profitabilitas dengan menggunakan return on asset serta rasio permodalan dengan menggunakan perhitungan capital adequacy ratio dan faktor eksternal yang diduga berpengaruh yaitu kurs dan suku bunga serta adanya perbedaan dari peneliti sebelumnya, maka perumusan masalah adalah apakah variabelvariabel independen loan to deposit ratio (LDR), retun on asset (ROA), capital adequacy ratio (CAR), kurs dan suku bunga berpengaruh terhadap variabel return saham sektor perbankan yang tercatat di Bursa Efek Indonesia? Berdasakan rumusan masalah, maka tujuan penelitian ini adalah mengetahui pengaruh variabel-variabel independen (loan to deposit ratio, retun on asset, capital adequacy ratio, kurs dan suku bunga) berpengaruh terhadap variabel return saham sektor perbankan yang tercatat di Bursa Efek Indonesia? 


\section{KAJIAN TEORI}

Pengertian dan peranan dari pasar modal adalah pasar yang menyediakan sumber pembelanjaan dengan jangka waktu yang relatif panjang, yang diinvestasikan pada barang modal untuk menciptakan dan memperbanyak alat-alat produksi dan akhirnya meningkatkan kegiatan perekonomian, pasar yang menjadi penghubung antara pemilik dana (pemodal=investor) dengan pengguna dana (emiten=perusahaan go publik) (Irmayanto dkk, 2009). Pencatatan pada papan utama harus memenuhi krieteria kegiatan operasional sekurang-kurangnya 36 bulan berturut-turut, laporan keuangan telah diaudit sekurang-kurangnya 3 tahun buku terakhir, aktiva berwujud bersih sekurangnya Rp100 miliar, pemegang saham pengendali sekurang-kurangnya 100 juta saham atau sekurangnya 35\% dari modal disetor dan jumlah pemegang saham paling sedikit 1 lot saham (Peraturan BEJ No.1.1 2004). Indeks Harga Saham Gabungan (IHSG) merupakan indeks yang mencerminkan pergerakan seluruh harga saham di bursa. Perhitungan Indeks Harga Saham secara umum dapat dihitung dengan menggunakan rumusan sebagai berikut (Sawidji, 2009). Investor didalam memilih saham tentunya mengharapkan keuntungan dengan harapan harga akan naik dan menghasilkan keuntungan ketika dilakukan penjualan, Menurut Jones (2000) return is yield dan capital gain (loss), Yield suatu cash flow yang dibayarkan secara periodik kepada pemegang saham (deviden) dan capital gain merupakan selisih antara harga saham pada saat pembelian dengan harga saham pada saat penjualan. Dari pengertian tersebut dapat dikemukakan bahwa return saham terdiri dari deviden dan capital gain (selisih harga sekarang dengan harga periode yang lalu). Dari pengertian return saham di dalam penelitian ini adalah selisih harga dari investasi sekarang dengan harga periode sebelumnya Untuk mengetahui kinerja bank, maka dilakukan analisa atas laporan keuangan, Menurut Irmayanto dkk (2009), analisa kinerja bank sebagai berikut: Likuiditas untuk melihat kemampuan bank dalam memenuhi kewajiban jangka pendeknya atau kewajiban yang sudah jatuh tempo. Salah satu rasio yang digunakan adalah Loan to Deposit Ratio (LDR) , untuk mengukur seberapa jauh kemampuan bank dalam membayar semua dana masyarakat serta modal sendiri dengan mengandalkan kredit yang telah didistribusikan ke masyarakat. Semakin tinggi rasio LDR berarti semakin rendah likuiditas bank, karena terlalu besar jumlah dana masyarakat yang dialokasikan ke kredit, disamping ratio LDR, ada juga Cash Ratio, Reserve Requitment, Loan to Asset Ratio; Permodalan untuk mengukur kemampuan bank dalam memenuhi kewajiban jangka panjangnya atau kewajiban bank untuk memenuhi kewajiban jika terjadi likuiditas bank turun. Perhitungan yang digunakan yaitu Capital Adequacy Ratio (CAR), mengukur seberapa jauh aktiva bank yang mengandung resiko ikut dibiayai dari modal sendiri disamping memperoleh dana-dana dari sumber di luar bank. Semakin tinggi CAR berarti semakin bagus solvabilitas bank, karena modalnya semakin mampu menutup aktiva yang beresiko, disamping CAR, ada juga Debt to Equity Ratio (DER), Long Term Debt to Asset Ratio (LTDAR). Profitabilitas untuk mengukur tingkat efisiensi usaha, kemampuan memperoleh laba dan tingkat kesehatan bank. Perhitungan yang digunakan yaitu Return on Asset (ROA) yang mengukur kemampuan aset bank dalam memperoleh keuntungan. Semakin tinggi $R O A$, semakin baik produktivitas aset dalam memperoleh keuntungan bersih, disamping ROA, ada juga Return on Equity (ROE), Operational Cost Ratio dan Net Profit Margin; Kurs menurut Sadono Sukirno (2006), kurs mata uang asing menunjukkan harga atau nilai mata uang negara sesuatu negara dinyatakan dalam nilai mata uang negara lain. Kurs valuta asing dapat juga didefinisikan sebagai jumlah uang domestik yang dibutuhkan, yaitu banyaknya rupiah yang dibutuhkan, untuk memperoleh satu unit mata uang asing. Kurs diperlukan dalam hubungannya adanya perdagangan antar negara yang 
menggunakan mata uang yang berbeda. Penelitian dengan masuknya aliran modal dari luar negeri tergambar dari menguatnya mata uang Rupiah terhadap mata uang USD yang terjadi pada akhir tahun 2010 yang secara bersamaan menguatnya Indeks Harga Saham gabungan IHSG sehingga mencapai rekor tertinggi yang terjadi di BEI. Kurs yang digunakan adalah kurs tengah akhir bulan yang dikeluarkan oleh Bank Indonesia. Suku bunga memegang peranan penting dalam setiap perekonomian yang merupakan indikator moneter, suku bunga yang tinggi menyebabkan investasi akan melambat. Dunia usaha akan berpengaruh dengan adanya kenaikan suku bunga khususnya sektor-sektor yang mengandalkan pembiayaan dari pinjaman (kredit), yang banyak dirasakan pada sektor riil. Untuk investor suku bunga tinggi sangat menguntungkan berbeda dengan peminjam, sehingga adanya pengendali yang dilakukan Bank Indonesia (BI).

Menurut Husnan (1998), tingkat suku bunga yang digunakan di Indonesia adalah tingkat suku bunga sertifikat Bank Indonesia (SBI). Sebagai patokan tingkat suku bunga SBI yang digunakan, bank-bank menentukan suku bunga berpatokan dari SBI dan suku bunga penjamin yang dikeluarkan oleh Lembaga Penjaminan Simpanan (LPS). Investor biasanya akan menarik dananya di pasar modal apabila suku bunga naik dan menginvestasikan kepada investasi yang berbasis suku bunga namun apabila mengalami suku bunga mengalami penurunan akan terjadi sebaliknya. Artinya bahwa suku bunga naik terjadi penurunan investasi di pasar modal, demikian pula sebaliknya suku bunga turun investasi di pasar modal naik terjadi hubungan yang negatip. Dari berbagai penelitian terdahulu dalam hubungannya dengan Loan To Deposit Ratio, Capital Adequacy Ratio, Return On Asset, kurs dan suku bunga sebagai bahan perbandingan dapat dikemukakan pada pengaruh internal perusahaaan yaitu peneliti Ria dan Sakti (2008) meneliti mengenai CAR. LDR, NPL, ROE, DPS terhadap harga saham dengan menggunakan model regresi berpendapat bahwa $C A R, L D R, N P L, R O A$ tidak mempunyai pengaruh terhadap harga saham berbeda dengan peneliti Asna dan Graha (2004) melakukan penelitian rasio keuangan terhadap return saham perbankan yang terdaftar di Bursa Efek Jakarta dengan menggunakan metode Purposing Sampling hasil analisinya rasio keuangan yang berpengaruh signifikan terhadap return saham adalah $L D R$ dan $B O P O$, sedangkan $C A R$ dan $R O A$ tidak berpengaruh signifikan untuk $L D R$ memiliki pengaruh yang kuat terhadap harga saham, tentunya berpengaruh terhadap return saham.

Penelitian yang dilakukan Hartono dan Sihotang (2009) dengan model analisi korelasional, mengenai hubungan profitabilitas dengan pergerakan harga saham pada sektor perbankan menunjukkan bahwa ROA tidak berpengaruh terhadap pergerakan saham dan berbeda dengan peneliti Timbul dan Widyo (2009) dengan model regresi, yang mengatakan bahwa ROA mempunyai pengaruh yang signifikan terhadap saham perbankan, sehingga faktor internal perusahaan yang berupa kinerja keuangan perusahaan untuk diteliti kembali dengan metode dan data yang berbeda. Pada eksternal perusahaan, Sembiring (2009) dalam penelitannya dengan metode regresi menyatakan bahwa IHSG dan SBI memberikan pengaruh yang besar terhadap nilai aktiva bersih reksadana campuran yang komponennya terdiri dari saham dan deposito. Peneliti Henry (1993) dengan metode ARIMA bahwa suku bunga dan nilai tukar tidak mempunyai hubungan yang signifikan terhadap harga saham, sedangkan Sridadi (2005) dengan model analisa dinamik, regresi time series dengan hasil IHSG, right issue dan kurs berpengaruh signifikan terhadap volume perdagangan saham sedangkan suku bunga SIBOR tidak mempunyai pengaruh terhadap volume perdagangan saham. Peneliti Bustami (2002) dengan metode regresi sederhana mengemukakan perubahan kurs sangat mempengaruhi return saham dan peneliti Ulupuai (2007) dengan metode vector auto regression (VAR) mengatakan pengaruh kurs USD berpengaruh terhadap IHSG. Dengan berbagai peneliti 
adanya perbedaan tersebut maka perlu dilakukan penelitian lebih lanjut. Adapun Menurut Tjiptono \& Hendy (2008), harga saham mengalami fluktuasi naik maupun turun karena terjadinya pembentukan harga permintaan dengan penawaran atas saham tersebut. Penawaran dan permintaan terjadi karena berbagai faktor, baik yang sifatnya spesifik atas saham (kinerja perusahaan dan industri di mana perusahaan tersebut bergerak), maupun faktor yang sifatnya makro seperti kondisi ekonomi negara, kondisi sosial politik, maupun rumor-rumor yang berkembang. Dari uraian ini dapat diuraikan bahwa return saham dapat dipengaruhi oleh faktor intern perusahaan (emiten) berupa kinerja keuangan, manajemen dan sebagainya dan faktor ekstern yaitu kondisi ekonomi seperti perubahan kurs, perubahan suku bunga, kebijaksanaan fiskal, dan lainnya Faktor intern perusahaan yang diamati investor adalah performance perusahaan yang dinilai dari besarnya laba perusahaan hubungannya dengan harga saham. Menurut Zaenal Arifin (2007), karena banyaknya model penilaian saham maka adanya metode penilaian saham lanjutan, yang diulas hubungan antara laba perusahaan dengan harga saham dengan uji earning responsiveness, dalam studi ini Ball dan Brown (didalam Zaenal Arifin, 2007), menganalisa kandungan informasi berupa laba tahunan, bahwa laba memiliki kandungan informasi yang tinggi sehingga secara signifikan membuat harga saham naik, kemudian studi tentang ramalan laba analis keuangan oleh Brown dan Rozeff (di dalam Zaenal Arifin, 2007) yang menunjukkan adanya superioritas prediksi laba oleh analis keuangan yang berpengaruh terhadap harga saham. Faktor internal perusahaan dinilai dari kinerja perusahaan berupa laba yang merupakan kegiatan perusahaan didalam menggunakan sumber dayanya yang secara efektif dan efisen dengan mendapatkan hasil maksimal. Berdasarkan hal tersebut $L D R, R O A$ dan $C A R$ sebagai ukuran kinerja perusahaan mempunyai pengaruh positip terhadap harga saham. Kenaikan harga saham tentunya mempengaruhi kenaikan return saham. Faktor ekstern perusahaan merupakan faktor di luar kendali perusahaan, seperti perubahan mata uang, suku bunga, pajak, inflasi dan lainnya. Terkait dengan harga saham yang berpengaruh ke return saham menurut Zaenal Arifin (2007), bahwa adanya pengaruh pengumuman kondisi ekonomi makro terhadap return saham, pertumbuhan ekonomi akan meningkatkan laba perusahaan sehingga akan berpengaruh positif terhadap harga saham namun dengan pertumbuhan ekonomi membawa meningkatnya permintaan kredit dan meningkatkan suku bunga yang akhirnya meningkatkan discount rate yang berarti menurunkan laba. Berdasarkan tinjauan pustaka, tujuan penelitian dan penelitian sebelumnya maka kerangka pemikiran antara $L D R, R O A$, CAR, Kurs dan Suku Bunga dapat dilihat pada Gambar 1. di bawah ini:

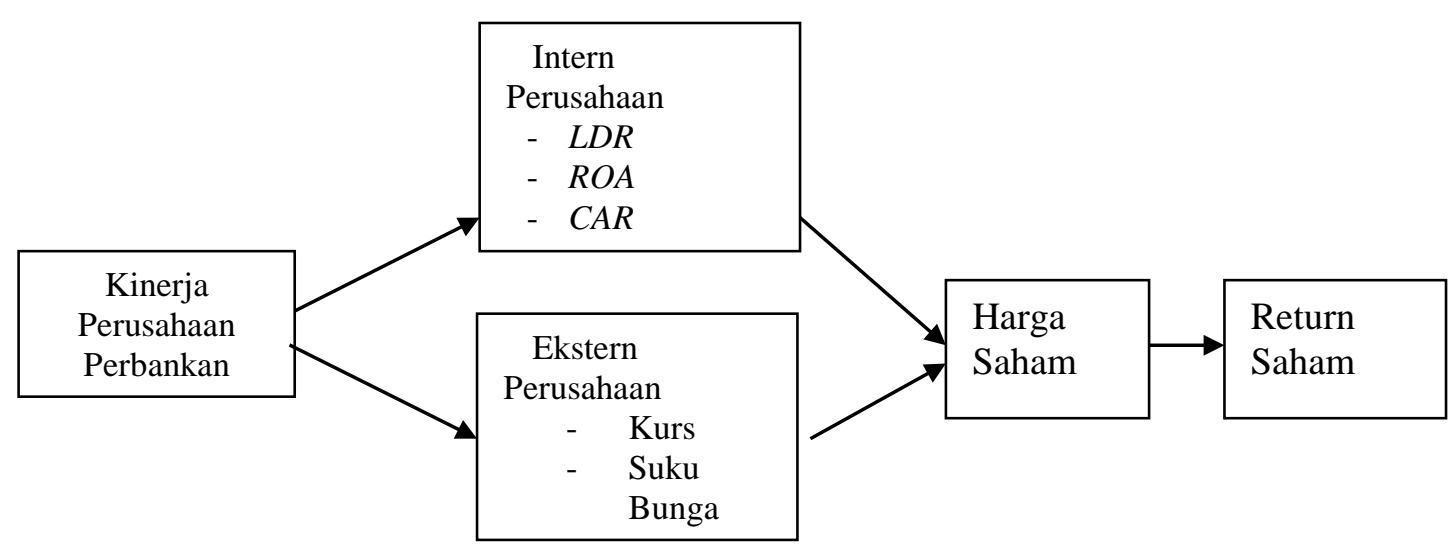

Gambar 1. Model Pengaruh LDR, ROA, CAR, Kurs dan Suku Bunga Terhadap Return Saham 
Ilustrasi di atas pada Gambar 1. menggambarkan kinerja perusahaan perbankan dari segi intern perusahaan yang berupa struktur modal dalam laporan keuangan yang terdiri dari aset perusahan, pendapatan perusahaan dan biaya perusahaan dalam penelitian ini digambarkan dalam $L D R, R O A$ dan $C A R$ yang mencerminkan harga saham. Harga saham juga dipengaruhi dari segi ekstern perusahaan yang dalam penelitian ini kurs dan suku bunga yang merupakan keputusan investasi dan terbentuk harga saham. Pembentukan harga saham ini menimbulkan adanya return saham yang berupa capital gain dan dimungkinkan adanya dividen yield. Dari pemaparan di atas maka secara ringkas diajukan hipotesis. Hipotesis yang menyatakan hubungan yang diduga secara logis antara dua variabel atau lebih dalam rumusan proposisi yang dapat di uji secara empiris. Berdasarkan tinjauan pustaka, tujuan penelitian dan penelitian sebelumnya, maka hipotesis dapat dijabarkan dalam penelitian ini adalah:

Hipotesis 1: LDR berpengaruh positif dan signifikan terhadap Return Saham Hipotesis 2: ROA berpengaruh positif dan signifikan terhadap Return Saham Hipotesis 3: CAR berpengaruh positif dan signifikan terhadap Return Saham Hipotesis 4: Kurs berpengaruh positif dan signifikan terhadap Return Saham Hipotesis 5: Suku Bunga berpengaruh negatif dan signifikan terhadap Return Saham

Data yang digunakan dalam penelitian ini menggunakan data sekunder yaitu data yang sudah jadi dan berupa publikasi adapun datanya berbentuk time series perbulan periode 2005 sampai dengan 2010, yang diperoleh dari Jakarta Stock Exchange Yahoo Finance sektor perbankan, Bursa Efek Indonesia, yang berupa rata-rata harga saham, laporan keuangan perusahaan perbankan yang tercatat di BEI, kurs USD yaitu kurs tengan BI bulanan, Suku Bunga dari laporan bulanan Bank Indonesia yaitu SBI, situs BI, situs BEI, dan lain-lain yang menyangkut penelitian. Populasi merupakan suatu kumpulan yang lengkap dari elemen-elemen yang sejenis akan tetapi dapat dibedakan karena karakteristiknya seperti semua perusahaan yang go publik, semua pembeli saham perorangan, semua perusahaan pembeli saham, dan lainnya (Supranto,2004). Populasi dari penelitian ini seluruh perusahaan sektor perbankan yang terdaftar di Bursa Efek Indonesia selama periode penelitian 2005-2010 sebanyak 31 perusahaan perbankan. Pemilihan perusahaan perbankan diambil melalui metode purposive sampling dengan tujuan untuk mendapatkan sampel yang sesuai dengan tujuan penelitian. Metode ini diambil dikarenakan pengambilan sampel berdasarkan kriteria tertentu dan berbagai pertimbangan dengan kriteria sebagai berikut: (1) Perusahaan perbankan yang terdaftar di Bursa Efek Indonesia periode tahun 2005 sampai dengan tahun 2010; (2) Termasuk kelompok papan utama, aktif diperdagangan dan bukan saham tidur; (3) Tidak de-listing selama tahun 2005 - 2010 dan termasuk kelompok papan utama; (4) Perusahaan yang data-datanya lengkap baik variabel dependen maupun independen dari tahun 2005 - 2010 didapat dari laporan keuangan publikasi masing-masing perusahaan, Laporan Bulanan Bank-bank Umum, Indonesian Capital Market Directory (ICMD), JSX Watch (2005-2010), situs Bursa Efek Indonesia dan laporan lainnya; (5) Adapun data-data dapat di olah dan dianalisa.

\section{METODE}

Tehnik Pengumpulan Data. Teknik pengumpulan data dalam penelitian ini menggunakan data sekunder yaitu dengan data yang didapat dari Indonesian Capital Market Directory (ICMD) dan JSX Monthly Statistic, situs BEI, situs BI, data laporan 
publikasi bank-bank, data bulanan Bank Indonesia, data bulanan kurs tengah Bank Indonesia dan data suku bunga Sertifikat Bank Indonesia (SBI) 1 bulan untuk periode Januari tahun 2005 sampai dengan Desember tahun 2010. Definisi operasional variabel adalah pengertian dari variabel-variabel yang digunakan dalam penelitian ini, dan menunjukkan cara pengukuran dari masing-masing variabel tersebut. Pada setiap indikator dihasilkan dari data sekunder dan dari suatu perhitungan terhadap formulasi yang mendasarkan pada konsep teori. Teknik yang digunakan berupa analisa kuantitatif, hubungan fungsional antara satu variabel dependen dengan variabel independen dapat dilakukan dengan regresi berganda dan menggunakan data gabungan antara cross section dan time series (data panel). Penggunaan data panel artinya bentuk data berstruktur time series sekaligus cross section, kendala yang dihadapi biasanya dalam penelitian ditemukan data series yang minim jangka waktu sehingga dalam pengolahan data terjadinya kesulitan dan juga data cross section mengalami kendala tidak lengkap sehingga dalam menggunakan teknik pengolahan menggunakan data panel (pooled data). Alat yang dipakai dalam pengolahan data dengan menggunakan program eview Dalam analisa model data panel sebelumnya ada 3 (tiga) jenis pendekatan atau model yang terdiri dari:

Pendekatan Kuadrat Terkecil (Pooled Least Square). Pendekatan model yang sederhana dalam pengolahan data panel bahwa dengan melakukan penggabungan atau data yang telah digabungkan (Pooled). Model ini disebut juga Commond model, misalkan terdapat persamaan sebagai berikut:

$$
Y_{i t}=\square+x^{j}{ }_{i t} \beta_{j}+\square \quad \text { untuk } i=1,2, \ldots, N \text { dan } t=1,2, \ldots, T
$$

Pendekatan Efek Tetap (Fixed Effect). Kesulitan terbesar dalam pendekatan metode kuadrat terkecil biasa tersebut adalah asumsi intersep dan slope dari persamaan regresi yang dianggap konstan baik antar daerah maupun antar waktu.. Generalisasi secara umum sering dilakukan adalah dengan memasukkan variabel boneka (dummy variable) untuk mengizinkan terjadinya perbedaan nilai parameter yang berbeda-beda baik lintas unit cross section maupun antar waktu. Dalam hal ini menyoroti nilai intersep yang mungkin saja bisa berbeda-beda antar unit cross section kenudian lakukan proses data dengan menggunakan Fixed Effect, Random Effect, Pool Least Square yang ketiganya di pendekatan dengan memasukkan variabel boneka ini dikenal dengan sebutan model efek tetap (fixed effect) atau Least Square Dummy

Pendekatan Efek Acak (Random Effect). Berkaitan dengan hal ini, dalam model data panel dikenal pendekatan ketiga yaitu model efek acak (random effect). Dalam model efek acak, parameter-parameter yang berbeda antar daerah maupun antar waktu dimasukkan ke dalam error. Karena hal ini lah, model efek acak sering juga disebut model komponen error (error component model). Bentuk model efek acak ini dijelaskan pada persamaan berikut ini:

$$
\begin{aligned}
& Y_{i t}=\quad \square \\
& \square \text { it }=u_{i}+v_{t}+w_{i t}+\square
\end{aligned}
$$

Dan juga diasumsikan bahwa error secara individual, tidak saling berkorelasi begitu pula dengan error kombinasinya. Spesifikasi ini akan memberikan penilaian dengan menggunakan nilai Chi Square Statistics sehingga keputusan pemilihan model ditentukan secara statistik.

Pengujian Pemilihan Model. Setelah dilakukan analisa data maka memilih model dengan dilakukan beberapa pengujian, ada beberapa macam pengujian yaitu Uji Chow Test, Uji LM Test dan Uji Hausmann yang dijelaskan sebagai berikut: 
Uji Chow Test. Chow Test adalah pengujian F Statistics adalah pengujian untuk memilih apakah model yang digunakan Pooled Least Square atau Fixed Effect. Dalam pengujian ini dilakukan dengan hipotesa sebagai berikut:

$\mathrm{H}_{0}$ : Model Pooled Least Square (Restricted)

$\mathrm{H}_{1}$ : Model Fixed Effect (Unrestricted)

Dasar penolakan terhadap hipotesa nol tersebut adalah dengan menggunakan F Statistik seperti yang dirumuskan oleh Chow:

$$
\text { CHOW }=\frac{(R R S S-U R S S) /(N-1)}{U R S S /(N T-N-K)}
$$

Dari Uji Chow tersebut hasil yang diperoleh dapat dijadikan patokan untuk menerima atau menolak Ho bahwa adanya pembatasan nilai intersep antar individu adalah benar. Apabila hasil dari nilai Chow lebih besar dari pada F Tabel, maka menolak hipotesa nol, maka model yang digunakan bukan model Pooled Least Square, melainkan model Fixed Effect (unrestricted) dan apabila hasil dari nilai Chow lebih kecil dari pada F tabel, maka untuk menerima hipotesa nol yang berarti model digunakan adalah model Pooled Least Square (PLS).

Uji LM Tes. LM test adalah pengujian untuk memilih model PLS atau model Random Effect. Dalam pengujian ini dilakukan dengan hipotesa sebagai berikut:

$\mathrm{H}_{0}$ : Model Pooled Least Square (Restricted)

$\mathrm{H}_{1}$ : Model Random Effect (Unrestricted)

Dasar penolakan terhadap hipotesa nol tersebut adalah dengan menggunakan tabel distribusi chi_square seperti yang dirumuskan oleh Breusch_Pagan:

$\mathrm{LM} \quad=\frac{n T}{2(T-1)}\left[\frac{\sum_{i=1}^{n}\left[\sum_{t=1}^{T} e_{i t}\right]^{2}}{\sum_{i=1}^{n} \sum_{t=1}^{n} e_{i t}^{2}}-1\right]^{2}$

Dari LM Test tersebut hasil yang diperoleh dapat dijadikan patokan untuk menerima atau menolak Ho bahwa adanya pembatasan nilai intersep antar individu adalah benar. Apabila hasil dari nilai $L M$ Tes lebih besar dari pada chi squares, maka menolak hipotesa nol, maka model yang digunakan bukan model Pooled Least Square, melainkan model Random Effect dan apabila hasil dari nilai LM Test lebih kecil dari pada Chi Square, maka untuk menerima hipotesa nol yang berarti model digunakan adalah model Pooled Least Square.

Uji Hausmann. Adalah pengujian untuk memilih model Fixed Effect atau model Random Effect. Dalam pengujian ini dilakukan dengan hipotesa sebagai berikut:

$\mathrm{H}_{0}$ : Model Fixed Effect

$\mathrm{H}_{1}$ : Model Random Effect (Unrestricted)

Model Hausmann menggunakan REM sebagai patokan (null hipotesis). Jika statistik uji menunjukkan penolakan hipotesis null maka FEM paling tepat dan sebaliknya REM jika hipotesis null tidak dapat ditolak. Pengujian ini menggunakan nilai chi square.

Gangguan-Gangguan Dalam Data Panel. Untuk memenuhi syarat BLUE (Best Linier Unbiasad Estimator), yaitu tidak mengganggu asumsi regresi, jika terjadi gangguan maka dilakukan perbaikan. Adapun uji asumsi klasik yang digunakan untuk mengetahui gangguan adalah sebagai berikut: 
Uji Akar Unit (Unit Root Test). Merujuk pada Nachrowi (2006), Pengujian Uji Akar Unit bertujuan untuk menguji apakah variabel-variabel yang terdapat dalam model stasioner atau tidak, artinya variabel dengan rentang waktu tertentu (data time series) akan stasioner jika rata-rata varians, maupun covarians setiap tahun pada variabel tersebut adalah konstan. Data time series menyimpan berbagai permasalahan. Salah satunya adalah autokorelasi, hal ini yang menyebabkan data tidak stasioner, sehingga apabila data dapat distasionerkan maka autokorelasi akan hilang dengan sendirinya. Uji yang biasa digunakan adalah Uji Augmented Dickey Fuller. Uji lain yang serupa yaitu Uji PhillipsPerron, keduanya mengindikasikan keberadaan akar unit sebagai hipotesis null. Dapat diketahui bahwa data yang dikatakan stasioner adalah data yang bersifat flat, tidak mengandung komponen trend, dengan keragaman yang konstan, serta tidak terdapat fluktuasi periodik. Untuk diketahui adanya akar unit, maka dilakukan pengujian Dickey Fuller (DF Test), dan kesimpulan hasil root test diperoleh dengan membandingkan nilai thitung dengan t-tabel Dickey Fuller.

Uji Kointegrasi. Uji ini merupakan lanjutan dari uji akar unit dan uji derajat integrasi. Dalam uji kointegrasi ini bertujuan guna mengkaji nilai residual dan persamaan didalam penelitian ini kointegrasi stasioner atau tidak, dalam arti guna mengetahui ada atau tidaknya hubungan jangka panjang antara variabel bebas dan varibel terikat lainnya

Pengujian Hipotesis. Untuk menguji hipotesis yang ada maka digunakan analisis regresi berganda, alat analisis ini digunakan untuk mengetahui pengaruh variabel $L D R, R O A$, $C A R$, Kurs dan Suku bunga terhadap return saham perbankan.

Pengujian Dengan Koefisien Regresi Secara Simultan (Uji Serentak). Pengujian terhadap koefisien regresi secara simultan atau uji serentak dilakukan dengan uji $F$. Pengujian ini dilakukan untuk mengetahui pengaruh semua variabel independen yang terdapat di dalam model secara bersama-sama (simultan). Dengan tingkat signifikansi sebesar 5\% nilai $\mathrm{F}$ dari masing-masing koefisien regresi kemudian dibandingkan dengan nilai $\mathrm{t}$ tabel, Jika Frasio $>$ Ftabel atau prob-sig $<\mathrm{a}=5 \%$ berarti bahwa masing-masing variable independen berpengaruh secara positif dan signifikan terhadap variabel dependen.

Pengujian Dengan Koefisien Regresi Parsial (Uji Individu). Pengujian terhadap koefisien regresi secara parsial atau uji individu dilakukan dengan uji $\mathrm{T}$, pengujian ini dilakukan untuk mengetahui signifikansi peran secara parsial antara variable independen terhadap variabel dependen dengan mengasumsikan bahwa variabel independen lain dianggap konstan. Dengan tingkat signifikansi sebesar 5\% nilai t hitung dari masingmasing koefisien regresi kemudian dibandingkan dengan nilai t tabel. Jika t-hitung $>\mathrm{t}-$ tabel atau prob-sig $<\mathrm{a}=5 \%$ berarti bahwa masing-masing variabel independen berpengaruh secara positif terhadap variabel dependen.

Koefisien Determinasi (Goodness of Fit Model). Koefisien determinasi $\mathrm{R}^{2}$ merupakan besaran yang memberikan informasi gooness of fit dari persamaan regresi yaitu memberikan proporsi atau persentase kekuatan pengaruh variable yang menjelaskan secara simultan terhadap variasi dari variabel dependen (Y). Besarnya koefisien determinasi $\mathrm{R}^{2}$ antara 0 sampai dengan 1 . Semakin mendekati 1 , maka model tersebut semakin baik dan mampu menjelaskan hampir 100\% dari variasi dalam variabel dependen. 


\section{HASIL DAN PEMBAHASAN}

Analisa yang berhubungan dengan data-data, metode yang digunakan yang telah dijelaskan pada sebelumnya. Dalam penelitian ini, variabel-variabel yang digunakan adalah lima variabel bebas dan satu variabel terikat. Kelima variabel bebas tersebut masing-masing adalah $L D R, R O A, C A R$, Kurs dan Suku Bunga. Sedangkan yang dijadikan sebagai variabel terikatnya adalah Return Saham.

Tabel .1 Hasil Uji Akar Unit Metode Augmented Dickey Fuller (ADF)

\begin{tabular}{cccc}
\hline VARIABEL & STATISTIK & PROBABILITY & STASIONER \\
\hline SAHAM & $1.904,68$ & $0,0000^{* * *}$ & $1^{\mathrm{ST}}, \mathrm{NONE}$ \\
LDR & $2.102,07$ & $0,0000^{* * *}$ & $1^{\mathrm{ST}}, \mathrm{NONE}$ \\
ROA & $2.042,24$ & $0,0000^{* * *}$ & $1^{\mathrm{ST}}, \mathrm{NONE}$ \\
CAR & $2.419,29$ & $0,0000^{* * *}$ & $1^{\mathrm{ST}}, \mathrm{NONE}$ \\
SUKU BUNGA & $3.084,74$ & $0,0000^{* * *}$ & $1^{\mathrm{ST}}, \mathrm{NONE}$ \\
KURS & $2.240,58$ & $0,0000^{* * *}$ & $1^{\mathrm{ST}}, \mathrm{NONE}$ \\
\hline
\end{tabular}

Sumber: Data diolah

Ket : * Signifikan pada alpha 10\% ** Signifikan pada alpha 5\% *** Signifikan pada alpha $1 \%$

Berdasarkan hasil pengujian akar unit dapat terlihat pada Tabel $1 \mathrm{di}$ atas, untuk keenam variabel yang terdapat didalam model atau persamaan yaitu Return Saham, $L D R, R O A$, $C A R$, SBI dan Kurs sudah stationer pada derajat 1. Hal ini dikarenakan keenam variabel dalam penelitian ini sudah memiliki nilai probabilitas dibawah 0,05 (alpha 5\%).

Uji Kointegrasi. Bertujuan untuk mengkaji nilai residual dari persamaan didalam penelitian ini kointegrasi stationer atau tidak.

Tabel .2 Hasil Uji Akar Unit Dickey Fuller

\begin{tabular}{cccc}
\hline Persamaan & Statistik & Probability & Stasioner \\
\hline Return Saham $=$ & $1,139.17$ & $0,0000^{* * *}$ & Level, None \\
f(LDR,ROA,CAR,SBI,KURS) & & & \\
\hline
\end{tabular}

Sumber: Data diolah

Ket : * Signifikan pada alpha 10\% ** Signifikan pada alpha 5\% *** Signifikan pada alpha $1 \%$

Berdasarkan Tabel 2 di atas pengujian kointegrasi yang menggunakan metode Dickey Fuller (DF) pada residual model regresi menunjukkan nilai probabilitas 0.000 lebih kecil dari alpha 0.01 (alpha 1\%). Hal ini menandakan residual yang dihasilkan oleh persamaan stasioner pada level (derajat 0), sehingga disimpulkan dalam jangka panjang variabelvariabel pada dalam model atau persamaan sudah berkointegrasi.

Pemilihan Model Estimasi Data Panel. Didalam analisa data panel dikenal ada 3 (tiga) macam pendekatan yaitu Pooled Least Square (Common Effect), Fixed Effect dan Random Effect. Hasil estimasi ketiga tersaji pada Tabel 3. Pendekatan Common Effect adalah lebih sederhana yang disebut juga dengan metode kuadrat terkecil biasa diterapkan dalam data 
berbentuk pool, adanya keputusan memasukkan variabel boneka dikenal sebagai Fixed Effect atau least square dummy variable, Random Effect merupakan keputusan memasukkan variabel boneka dalam model efek tetap tidak dapat dipungkiri, parameterparameter yang berbeda antar daerah atau antar waktu dimasukkan ke dalam error.

Tabel 3. Perbandingan Hasil Estimasi

\begin{tabular}{|c|c|c|c|c|c|c|}
\hline Variabel & $\begin{array}{c}\text { Common Effe } \\
\text { Koefisien }\end{array}$ & & $\begin{array}{c}\text { Fixed Effect } \\
\text { Koefisien }\end{array}$ & & $\begin{array}{c}\text { Random Ef } \\
\text { Koefisien }\end{array}$ & ffect \\
\hline Saham & $-1,588455$ & & $-2,115189$ & & $-1,1588$ & \\
\hline LDR & 2,17E-05 & & $-3,33 E-06$ & & 5,38E-05 & \\
\hline ROA & 0,934801 & $* * *$ & 0,933273 & $* * *$ & 0,936151 & $* * *$ \\
\hline CAR & 0,009138 & & 0,020592 & & 0,005502 & \\
\hline SBI & 0,010067 & & 0,009182 & & 0,01097 & \\
\hline Kurs & 8,13E-05 & & 0,000103 & & 4,51E-05 & \\
\hline $\mathrm{R}^{2}$ & 0,593398 & & 0,595116 & & 0,590512 & \\
\hline Adjusted $\mathrm{R}^{2}$ & 0,591212 & & 0,587618 & & 0,58831 & \\
\hline F-Statistik & 271,4499 & $* * *$ & 79,37141 & $* * *$ & 271,4499 & $* * *$ \\
\hline
\end{tabular}

Sumber: Data diolah

Ket : * Signifikan pada alpha $10 \% \quad * *$ Signifikan pada alpha $5 \% \quad * * *$ Signifikan pada alpha $1 \%$

Tabel 4. Hasil Estimasi Chow Test

\begin{tabular}{|c|c|c|c|}
\hline Metode & $\begin{array}{l}\text { Probabilita } \\
\text { Chi-square }\end{array}$ & Keputusan & Keterangan \\
\hline & \multicolumn{3}{|c|}{ Ho } \\
\hline Chow Test & 0,9841 & Diterima & Common Effect \\
\hline
\end{tabular}

Dengan melakukan pengujian menggunakan Chow Test dimana hipotesa nol $\left(\mathrm{H}_{0}\right)$ adalah model Common Effect diperoleh nilai probabilitas dari Chi Square sebesar 0,9841 > 0,05. Dengan demikian hipotesa nol $\left(\mathrm{H}_{0}\right)$ diterima, sehingga model yang lebih baik digunakan adalah estimasi dengan Common Effect pada Tabel 4 Namun pengujian selanjutnya adalah membandingkan Common Effect dengan Random Effect dimana pengujian menggunakan LM Test dapat dilihat pada Tabel 5.

Tabel 5. Hasil Estimasi LM Test

\begin{tabular}{|c|c|c|c|}
\hline Metode & $\begin{array}{l}\text { Statistik } \\
\text { LM }\end{array}$ & Keputusan & Keterangan \\
\hline LM Test & 2872224869 & Ho Ditolak & Random Effect \\
\hline
\end{tabular}

Hasil perhitungan statistik $L M$ berdasarkan residual metode Common Effect didapatkan nilai statistik $L M$ sebesar 2872224869, sedangkan nilai kritis tabel distribusi chi square dengan df sebesar 5 pada alpha 1\% dan alpha 5\% masing-masing sebesar 15,0863 dan 16,7496. Dengan demikian secara statistik signifikan sehingga diputuskan menolak 
hipotesa null dan disimpulkan Random Effect lebih tepat digunakan untuk mengestimasi model yang diajukan dalam penelitian ini.

Pengujian Hipotesa. Pada Tabel 6 yang merupakan estimasi dengan menggunakan metode Random Effect berdasarkan Goodness of Fit Model, Uji Serentak (Uji F) dan Uji Individu (Uji T) dapat dijelaskan sebagai berikut:

Tabel 6. Hasil Estimasi Metode Random Effect

\begin{tabular}{lrll}
\hline \multicolumn{1}{r}{ Variabel } & Koefisien & & Std Error \\
\hline C & $-1,158798$ & & 2,651451 \\
LDR & $5,38 \mathrm{E}-05$ & & 0,000462 \\
ROA & 0,936151 & $* * *$ & 0,025219 \\
CAR & 0,005502 & & 0,007263 \\
SBI & 0,010970 & & 0,008448 \\
Kurs & $4,51 \mathrm{E}-05$ & & 0,000272 \\
R-Squared & & 0,590512 & \\
Adjusted R-Square & & 0,588310 & \\
F-Stat & & 271,449 & \\
Prob F-Stat & & 0,000000 & \\
\hline
\end{tabular}

Ket : * Signifikan pada alpha $10 \% \quad * *$ Signifikan pada alpha $5 \% \quad * * *$ Signifikan pada alpha $1 \%$

Rumusan:

$S A H A M=\beta_{0}+\beta_{1} L D R+\beta_{2} R O A+\beta_{3} C A R+\beta_{4} S B I+\beta_{5} K U R S+\varepsilon$

Goodness of Fit Model. Berdasarkan hasil pengolahan dengan metode Random Effect didapatkan nilai dari Adjusted R-square sebesar 58,83\%, hal ini menunjukkan kemampuan dari seluruh variabel independen dalam menjelaskan variasi dari variabel dependent sebesar 58,83\% sedangkan sisanya sebesar 41,17\% dijelaskan oleh variabel independen lain yang tidak dimasukkan kedalam model.

Uji Serentak (Uji F). $\mathrm{H}_{6}$ : Secara simultan terdapat pengaruh $L D R, R O A, C A R$, SBI dan Kurs terhadap Return Saham. Nilai F-stat yang menggambarkan uji ketepatan model adalah sebesar 271,4499, dengan probabiliti F-stat sebesar 0.000, maka hipotesa alternatif diterima dan disimpulkan pada tingkat kepercayaan 99\%, variabel-variabel independen secara bersama-sama mempunyai pengaruh yang signifikan terhadap variabel dependen.

Uji Individu (Uji T). Pengujian individual atau uji T-stat dan probabilitas digunakan untuk menguji apakah koefisien regresi parsial berbeda secara individu berhubungan dengan variabel dependen. Berdasarkan hasil estimasi dengan menggunakan metode Random Effect, dapat diinterpretasikan sebagai berikut:

a. LDR. Adapun hipotesa 1 untuk variabel $L D R$ bahwa:

$\mathrm{H}_{1}$ : Terdapat pengaruh positif dan signifikan $L D R$ terhadap Return Saham

Dari hasil pengujian individu didapat hasil koefisien $L D R$ :

$$
\beta=538 \mathrm{E}-05
$$

Artinya, jika $L D R$ naik sebesar 1\%, maka Return Saham naik sebesar 538E-05\%, dengan asumsi ceteris paribus. Estimasi yang dihasilkan sesuai dengan hipotesa yang diajukan 
dalam penelitian ini, dimana $L D R$ memiliki pengaruh positif terhadap return saham. Hasil pengujian statistik menunjukkan besarnya nilai probabilita sebesar 0,9074 $>0,10$, maka disimpulkan menolak hipotesa alternatif. Oleh karena itu dapat disimpulkan hanya terjadi kecenderungan jika $L D R$ meningkat maka akan meningkatkan return saham.

b. ROA. Adapun hipotesa 2 untuk variabel $R O A$ bahwa:

$\mathrm{H}_{2}$ : Terdapat pengaruh positif dan signifikan $R O A$ terhadap Return Saham

Dari hasil pengujian individu didapat hasil koefisien $R O A$ :

$ß=0,936151$

Artinya, jika ROA naik sebesar 1\%, maka Return Saham naik sebesar 0,936151\%, dengan asumsi ceteris paribus. Estimasi yang dihasilkan sesuai dengan hipotesa yang diajukan dalam penelitian ini, dimana $R O A$ memiliki pengaruh positif terhadap return saham. Hasil pengujian statistik menunjukkan besarnya nilai probabilita sebesar $0,000<0,01$, maka disimpulkan menerima hipotesa alternatif. Oleh karena itu dapat disimpulkan terdapat pengaruh positif $R O A$ terhadap return saham, dimana pengaruh yang diberikan signifikan pada tingkat kepercayaan $99 \%$.

c. $\boldsymbol{C A R}$. Adapun hipotesa 3 untuk variabel $C A R$ bahwa:

$\mathrm{H}_{3}$ : Terdapat pengaruh positif dan signifikan $C A R$ terhadap Return Saham

Dari hasil pengujian individu didapat hasil koefisien $C A R$ :

$ß=0,005502$

Artinya, jika CAR naik sebesar 1\%, maka Return Saham naik sebesar 0,005502\%, dengan asumsi ceteris paribus. Estimasi yang dihasilkan sesuai dengan hipotesa yang diajukan dalam penelitian ini, dimana $C A R$ memiliki pengaruh positif terhadap return saham. Hasil pengujian statistik menunjukkan besarnya nilai probabilita sebesar 0,4489 $>0,10$, maka disimpulkan menolak hipotesa alternatif. Oleh karena itu dapat disimpulkan hanya terjadi kecenderungan jika $C A R$ meningkat maka akan meningkatkan return saham.

d. Kurs. Adapun hipotesa 4 untuk variabel Kurs bahwa:

$\mathrm{H}_{4}$ : Terdapat pengaruh positif dan signifikan Kurs terhadap Return Saham

Dari hasil pengujian individu didapat hasil koefisien Kurs:

$ß=4,51 \mathrm{E}-05$

Artinya, jika Kurs naik sebesar Rp 1, maka Return Saham naik sebesar 4,51E-05\%, dengan asumsi ceteris paribus. Estimasi yang dihasilkan sesuai dengan hipotesa yang diajukan dalam penelitian ini, dimana Kurs memiliki pengaruh positif terhadap return saham. Hasil pengujian statistik menunjukkan besarnya nilai probabilita sebesar 0,8683 > 0,10, maka disimpulkan menolak hipotesa alternatif. Oleh karena itu dapat disimpulkan hanya terjadi kecenderungan jika Kurs meningkat maka akan meningkatkan return saham.

e. SBI. Adapun hipotesa 5 untuk variabel SBI bahwa:

$\mathrm{H}_{5}$ : Terdapat pengaruh negatif dan signifikan SBI terhadap Return Saham

Dari hasil pengujian individu didapat hasil koefisien SBI:

$ß=0,010970$

$\mathrm{H}_{5}$ : Terdapat pengaruh negatif dan signifikan SBI terhadap Return Saham

Artinya, jika SBI naik sebesar Rp 1, maka Return Saham naik sebesar 4,51E-05\%, dengan asumsi ceteris paribus. Estimasi yang dihasilkan tidak sesuai dengan hipotesa yang diajukan dalam penelitian ini, dimana SBI memiliki pengaruh negatif terhadap return saham. Oleh karena pengujian statistik tidak dilanjutkan kembali dan disimpulkan tidak terdapat pengaruh SBI terhadap return saham.

Dari hasil data panel tersebut di atas maka yang berpengaruh positif dan signifikan terhadap return saham perbankan adalah $R O A$, sedangkan LDR, CAR dan Kurs hanya terjadi kecenderungan jika LDR, CAR dan Kurs meningkat maka akan meningkatkan return saham perbankan dan untuk SBI tidak mempunyai pengaruh terhadap return saham 
perbankan. Setelah dilakukan serangkaian uji, maka model Random Effect sebagai model dalam penelitian tersebut. Dengan mengacu pada model Random Effect dan hasil analisa maka dapat dijelaskan sebagai berikut:

Hipotesa 1. Menolak hipotesa yang menyatakan bahwa terdapat pengaruh positif dan signifikan $L D R$ terhadap return saham dan hanya terjadi kecenderungan jika $L D R$ meningkat maka akan meningkatkan return saham. Hal ini berbeda dengan penelitian oleh Asna dan Andi Nu Graha (2006) yang menyatakan LDR berpengaruh dominan terhadap return saham tetapi tidak dengan penelitian Fanny dan Sakti (2008) yang menjelakan bahwa LDR tidak berpengaruh terhadap return saham.

Hipotesa 2. Menyatakan bahwa ROA berpengaruh positip dan signifikan terhadap return saham perbankan, dengan demikian pernyataan bahwa ROA berpengaruh positif dan signifikan pada return saham perbankan dapat diterima. Hasil ini sejalan dengan peneliti Ucok Saut (2009) yang menyatakan bahwa ROA mempunyai pengaruh yang signifikan terhadap harga saham perbankan. Namun peneliti Hartono dan Raymundus (2009) dan Asna dan Graha (2006) menyatakan ROA tidak berpengaruh terhadap return saham. Dengan adanya perbedaan hasi penelitian, peneliti berpendapat bahwa kurun waktu data yang diambil dari 2005-2010 dengan menggunakan data panel membuktikan ROA berpengaruh dengan return saham, kenaikan $R O A$ membuktikan usaha perbankan dijalankan secara efisien terhadap sumber-sumber yang ada sehingga menaikkan laba perusahaan dan investor di pasar modal melihat kinerja perusahaan berjalan dengan baik sehingga meningkatkan performance perusahaan berakibat pada kenaikan deviden dan return saham.

Hipotesa 3. Menolak hipotesa yang menyatakan bahwa terdapat pengaruh positif dan signifikan CAR terhadap return saham dan hanya terjadi kecenderungan jika CAR meningkat maka akan meningkatkan return saham, hasil ini berbeda dengan peneliti Fanny Roswita dan Hasan Sakti (2008) serta Asna dan Graha (2006) yang berpendapat CAR tidak mempunyai pengaruh terhadap return saham.

Hipotesa 4. Menolak hipotesa yang menyatakan bahwa terdapat pengaruh positif dan signifikan Kurs terhadap return saham dan hanya terjadi kecenderungan jika Kurs meningkat maka akan meningkatkan return saham. Hal ini tidak sejalan dengan peneliti Bustami (2002) berpendapat kurs akan sangat mempengaruhi return saham dan I.G.K.A Ulupuai (2007) bahwa perubahan kurs USD berpengaruh kepada harga saham.

Hipotesa 5. Menyatakan bahwa suku bunga tidak berpengaruh positip dan tidak signifikan terhadap return saham sektor perbankan, karena tidak mempunyai hubungan dengan return saham perbankan, hasil penelitian ini konsisten dengan Henry (1993) dan Sridadi (2005), namun berbeda dengan peneliti Sembiring (2009).

\section{PENUTUP}

Simpulan. Berdasarkan hasil analisa peneliti yang telah ditetapkan, maka dapat dibuat kesimpulan sebagai berikut: (1) Dari hasil penelitian dengan menggunakan perhitungan statistik $L M$ test bahwa Random Effect lebih tepat digunakan untuk mengestimasi model dalam penelitian ini; (2) Hanya variabel $R O A$ yang didapat bahwa ada pengaruh yang signifikan dan positif antara $R O A$ dengan return saham secara parsial yang perhitungan dengan kenaikan pendapatan menaikkan kinerja perusahaan. Perusahaan dengan menggunakan faktor-faktor sumber daya yang dipunyai perusahaan serta menjalan secara efektip dan efisien akan menghasilkan peningkatan laba perusahaan. Pengaruhnya kenaikan harga saham karena investor melihat prospek terhadap perusahaan perbankan; 
(3) Sedangkan variabel $L D R$, $C A R$ dan Kurs tidak ada pengaruh yang signifikan terhadap return saham, dan hanya kecenderungan jika $L D R$, $C A R$ dan Kurs meningkat maka return saham dapat meningkat pula; (4) Sedangkan SBI tidak berpengaruh positip dan signifikan terhadap return saham sektor perbankan. Maka dari hasil pengujian yang menyatakan bahwa Suku Bunga berpengaruh negatif dan signifikan pada return saham perbankan tidak diterima, karena tidak mempunyai hubungan dengan return saham.

Dari ke 5 (lima) variabel dapat dinyatakan bahwa variabel $L D R, R O A$ dan $C A R$ yang merupakan kinerja perusahaan dari sisi internal, Variabel $R O A$ yang mempunyai pengaruh positif dan signifikan terhadap return saham pada perusahaan perbankan yang diteliti pada periode 2005 - 2010 pada Bursa Efek Indonesia. Dari sisi ekstern perusahaan yang diteliti hanya variabel Kurs dan SBI. Terhadap variabel SBI tidak mempunyai pengaruh terhadap return saham pada perusahaan perbankan dalam periode penelitian 2005 - 2010 pada Bursa Efek Indonesia.

\section{DAFTAR RUJUKAN}

Agus Sartono R, (2001) “Manajemen Keuangan: Teori dan Aplikasinya”, Yogyakarta: BPFE-Yogyakarta.

Asna dan Andi Nu graham, (2006) "Analisa Pengaruh Rasio Keungan Terhadap Return Saham Perbankan yang Terdaftar di Bursa Efek Jakarta”, Malang: Jurnal Ekonomi Modernisasi, Volume 2, (3), Oktober 2006.

Bank Indonesia, (2006) "Laporan Keuangan. Publikasi Available”, April 2006 ,UU Nomor 10 Tahun 1998 Tentang Perubahan UU Nomor 7 Tahun 1992 Tentang Perbankan, Jakarta, 1998.

,Peraturan Bank Indonesia No 3/21/PBI/2001 Tentang Kewajiban Penyediaan Modal Minimum Bank Umum, Jakarta, 2001.

Dahlan Siamat, (2005) "Manajemen Lembaga Keuangan: Kebijakan Moneter dan Perbankan”, Jakarta: Lembaga Penerbit Fakultas Ekonomi Universitas Indonesia”.

Daily Stock Price For Banking, Jakarta Stock Exchange, Januari 2004 - Maret 2009.

Dornbusch, Rudiger and Stanley Fischer, (2008) “Makro Ekonomi”, Jakarta: Media Global Edukasi.

Edi Subiyantoro dan Fransisca Adreani, (2004) "Analisa Faktor-faktor yang Mempengaruhi Harga Saham”, Jurnal Manajemen dan Kewirausahaan Vol.5 , Malang: Universitas Kristen Petra.

Ety Rochaety,.Ratih Tresnati dan Abdul Madjid Latief, (2009) Metodologi Penelitian Bisnis: Dengan Aplikasi SPSS, Jakarta: Mitra Wacana Media.

Fanny Roswita R dan Hasan Sakti S (2008) "Pengaruh Capital Adequacy Ratio (CAR), Loan To Deposit Ratio (LDR), Non Performing Loan (NPL), Return On Equity (ROE),dan Dividen per Share (DPS) terhadap Harga Saham pada Perusahaan Perbankan yang Terdaftar di Bursa Efek Indonesia". Medan: www.usu.ac.id/jurnal akuntansi.html?tmp.

Ferikawati Magdalena Sembiring, (2009) "Pengaruh Perubahan Indeks Harga Saham Gabungan (IHSG), Tingkat Bunga Obligasi Pemerintah dan Tingkat Bunga Sertifikat Bank Indonesia (SBI) terhadap Nilai Aktiva Bersih Reksadana Campuran pada periode 1 Januari 2004-31 Desember 2006”, Jakarta: Kartika Wijaya Kusuma, Majalah Ilmiah Vol. 17 (2) hal 126-136, Novemper.

Ghozali, (2006) Analisa Ekonometrika dengan Eviews, Semarang: Badan Penerbit UNDIP. 
Hartono dan Raymundus Parulian Sihotang, (2009) "Analisis Hubungan Prifitabilitas Dengan Pergerakan Harga Saham Pada Sektor Usaha Perbankan Di Bursa Efek Indonesia”, Jakarta: Journal of Applied Finance and Accounting”, Vol. 2 (1) 51-66, Binus, Nopember 2009.

Henry, (1993) "Casuality of Interest Rate, Exchange Rate.and Stock Price at Stock Market in Hongkong”, Hongkong: Asian Pasifik Journal of Management, Vol.10 p.123129.

Husnan, Suad, (2005) Dasar-dasar Teori Portfolio dan Analisa Sekuritas, Yogyakarta: UPP AMP YKPN.

Hsioa Ceng. (1986) Analysis of Panel Data. Chambridge University.

I.G.K.A. Ulupuai, (2007) "Pengaruh Kurs USD terhadap Indeks Harga Saham Gabungan di Bursa Efek Jakarta”, Yogyakarta: Jurnal Ekonomi dan Bisnis, Vol.19 (2), hal. 104-118, September.

Jones, Charles P, (2000) Investment: Analysis and Management, New York: John Willey and Sons. Inc.

Juli Irmayanto dkk. (2009) Bank \& Lembaga Keuangan, Jakarta: Penerbit Universitas Trisakti, Mei.

Kristanto Bustami, (2003) "Analisa Pengaruh Fluktuasi Nilai Tukar Terhadap Return Saham Perbankan (studi di Bursa Efek Jakarta)”, Digilib.unikom.ac.id/gdl.php?mod, Pebruari.

Nachrowi D Nachrowi dan Hardius Usman, (2006) Pendekatan Populer dan Praktis: Ekonometrika Untuk Analisis Ekonomi dan Keuangan, Jakarta: Lembaga Penerbit Fakultas Ekonomi Universitas Indonesia.

Nurul Qomariyah, (2010) 4 Alasan IHSG Bisa Spektakuler, Detik Finance, September.

Riahi-Belkaoui, (1997) "Value Relevance of Popular Financial Ratios”, Advance in Quantitative Analysis of Finance.

Sadono, Sukirno, (2006) “Makro Ekonomi: Teori Pengantar”, Jakarta: Raja Grafindo Persada.

Sahibul Munir, (2007) "Statistik Deskriptif:Analisa Korelasi Product Moment”. Jakarta: Pusat Pengembangan Bahan Ajar FE Mercu Buana.

Sawidji, Widoatmodjo, (2009) "Pasar Modal Indonesia: Pengantar \& Studi Kasus", Bogor Selatan: Ghalia Indonesia, April.

Selamet Riyadi, (2006) Banking Assets And Liability Management, Jakarta: Lembaga Penerbit Fakultas Ekonomi Universitas Indonesia.

Supranto, J, (2004) Statistik Pasar Modal: Keuangan \& Perbankan, Jakarta: Rineka Cipta, Pebruari.

Sridadi, (2005) “Analisis Fundamental terhadap Volume Perdagangan Saham”, Surabaya: Ekonomi dan Bisnis Vol.8 (1) Hal.59-68, Desember.

Tjiptono Darmadji dan Hendy M. Fakhruddin, (2008) Pasar Modal Di Indonesia: Pendekatan Tanya Jawab, Jakarta: Salemba Empat.

Winarno, W.W, (2009) Analisis Ekonometrika \& Statistika Dengan Eviews. $2^{\text {nd }}$ Ed., Yogyakarta: STIM YKPN.

Zaenal Arifin, (2007) Teori Keuangan dan Pasar Modal, Yogyakarta: Ekonisia. 